\title{
Diterpenoids of alepidea amatymbica eckl. \& zeyh: studies of their cytotoxic, antimicrobial and lipoxygenase inhibitory activities
}

\begin{abstract}
Alepidea amatymbica, an herbaceous plant with a broad ethnomedicinal application among the native of Eastern and Southern Africa. The isolation of diterpenoids from $A$. amatymbica and evaluation of their biological activities, based on the ethnomedicinal information, was the primary focus of this investigation. Five bioassay guided isolated diterpenoids: ent-13-hydroxy-16-kauren-19-oic acid (1), 16-hydroxy-kaur-6-en-19-oic acid (2), 14- acetoxy ent- kaur-16-en-19-oic acid (3), 14-oxokaur-16-en-19-oic acid (4), and 14-acetoxo-12-oxokaur-16-en-19-oic acid (5) were screened in vitro for their anti-inflammatory, cytotoxicity, and antimicrobial. The diterpenoids were isolated and purified using open column chromatography, PTLC, and characterised with FTIR, NMR, and HRMS EI. The diterpenoids were not cytotoxicity on the normal cell but showed a significant effect of cancer cell lines. 14-acetoxo-12-oxokaur-16-en-19-oic acid showed a high inhibitory effect on lipoxygenase with an $\mathrm{EC}_{50}$ of $19.10 \pm 3.15 \mu \mathrm{g} /$ $\mathrm{ml}$ compared to standard indomethacin with $\mathrm{EC}_{50}$ of $17.22 \pm 5.48 \mu \mathrm{g} / \mathrm{ml}$. Among the diterpenes isolated and tested, 14-oxokaur-16-en-19-oic acid and 14-acetoxo-12oxokaur-16-en-19-oic acid showed significant antibiotic activities against bacteria (MIC $125 \mu \mathrm{g} / \mathrm{ml}$ ) compared to gentamycin. Consequently, the antibiotic activity is structurally linked to the positions of acetate and oxo groups at C-14 and C-12 which enhances the activity of the diterpenoids. The in-vitro biological activities confirmed that the diterpenoids are sources of treatment and management of inflammationrelated diseases, justifying its traditional applications.
\end{abstract}

Keywords: a. amatymbica, diterpenoids, bioautographic assay, cytotoxicity, lipoxygenase
Volume I Issue 3 - 2017

\author{
Eddwina Muleya,' Okoli Bamidele Joseph, ${ }^{2}$ \\ Fanyana Moses Mtunzi, ${ }^{3}$ Modise Johannes \\ Sekomeng ${ }^{2}$ \\ 'Department of Chemical Technology, Midlands State University, \\ Zimbabwe \\ ${ }^{2}$ Institute of Chemical and Biotechnology, Vaal University of \\ Technology, South Africa \\ ${ }^{3}$ Department of Chemistry, Vaal University of Technology, South \\ Africa
}

\begin{abstract}
Correspondence: Okoli Bamidele Joseph, Institute of Chemical and Biotechnology, Vaal University of Technology, Southern Gauteng Science and Technology Park-Private Bag X021, Sebokeng 1983, South Africa, Tel +27767619418, Email bamideleo@vut.ac.za
\end{abstract}

Received: July 30, 2017 | Published: August 28, 2017
Abbreviations: $\mathrm{EC}_{50}$, half maximal effective concentration; MIC, minimum inhibitory concentration; TLC, thin-layer chromatography; PTLC, preparative thin layer chromatography; FTIR, fourier transform infrared spectroscopy; HRMS E, high-resolution mass spectrometer electron ionization; ${ }^{1} \mathrm{H}$ NMR; Proton Nuclear Magnetic Resonance; ${ }^{13} \mathrm{C}$ NMR; Carbon Nuclear Magnetic Resonance COSY, Homonuclear Correlation Spectroscopy; HSQC, heteronuclear single quantum coherence or heteronuclear single quantum correlation; HMBC, heteronuclear multiple bond correlation; ATCC: American type culture collection

\section{Introduction}

Alepidea amatymbica Eckl. \& Zeyh is associated with the genus Alepidea a member of the Apiaceae family and known as ikhathazo by the Zulu and larger tinsel flower by the British. It is one out of the twenty-eight species of commonly used medicinal plants, ${ }^{1}{ }^{1}$ endemic to lowlands of Eastern and Southern Africa. ${ }^{2,3}$ It is a herbaceous plant arising from a single branched rhizome with dark green leaves, which is used in the treatment of conditions such as malaria, diarrhoea, flu, chest complaints, asthma and rheumatism. ${ }^{4}$ Extract of this species is reported to be highly regarded as active against HIV. ${ }^{5}$

The developing world has been on the receiving end of the direct impact of infectious diseases on the human health, as a consequence of the unavailability of vaccines or limited chemotherapy. The recent upsurge in the trend of infectious diseases in the world with greater impact in the Sub-Sahara Africa has led to the continuous search of reliable alternative medicine. ${ }^{6}$ The anti-inflammation property of A. Amatymbica was evaluated to determine its potential for preventing the initiation and development of diseases such as cancer $^{7,8}$ The report on the ethnobotanical survey of medicinal plants in the south eastern, Karoo, South Africa, documented that over $80 \%$ of South Africa population depend on herbal medicine and this dependence on traditional medicine is due to the high cost of western medication. Reviews of $A$. amatymbica literature has revealed various pharmacological activities which include anti-Inflammatory, antibacterial, antifungal, antihelminthic, antimalarial, antihypertensive and diuretic activities. Also, the claimed ethnomedicinal efficacy of the plant has been linked to some secondary metabolites present. ${ }^{9}$ However, all these metabolites have not been tested individually. Some diterpenoids with promising activities have been isolated over the past decade from A. amatymbica such as ent-kaur-16-en-19-oic acid, $15 \beta$-Acetoxy-(-)-kaur-16-en-19-oic acid and 16 $\alpha$-Methoxy-entkaur-en-19-oic acid. ${ }^{10}$

The encouragement of WHO on the use of traditional medicine for the treatment and prevention of diseases and its broad ethnomedicinal application $^{11}$ have made the primary focus of this study the isolation and characterisation of diterpenoids from A. amatymbica. Consequentially, to evaluate the in vitro inhibitory activity against 15 -soybean lipoxygenase (15-LOX) enzyme, antibiotic, and cytotoxicity in normal Vero and cancerous bovine dermis cells. 


\section{Experimental}

\section{Chemicals}

All reagents and chemicals used in this study are from SigmaAldrich Chemicals Co., St Louis, MO, USA and are of analytical grade.

\section{Collection and Authentication of A. amatymbica root}

The selection of $A$. amatymbica was based on the ethnobotanical survey (oral interviews) with Mabandla village traditional healers of Umzimkhulu Local Municipality, Kwa-Zulu Natal, South Africa. The collection and identification of $A$. amatymbica roots were done by the head of traditional healers from the village (Mr S.P Dlamini). Authentication of the of A. amatymbica root was carried out by the South Africa National Biodiversity Institute, Pretoria, and voucher specimen number: 2116-0 was deposited at Pretoria National Botanical Garden.

\section{Maceration and liquid-liquid extraction}

Exactly, 2000g of A. amatymbica roots were air dried, pulverised using Lasec Polymix PX-MFC 90D grinder and macerated with acetone in a weight-solvent ratio of $1: 10 \mathrm{ml}$ for $6 \mathrm{~h} .{ }^{12}$ The extractants were recovered by use of a BUCHI Rotavapor R-210 with bath B-491 coupled to a vacuum pump V-210, and the resultant extract was air dried at ambient temperature in the fume hood under an air stream. The dried extract was re-dissolved in $70 \%$ acetone and sequentially partitioned with hexane, dichloromethane, ethyl acetate, acetone, methane, and water (freeze-dried at $-55^{\circ} \mathrm{C}$ for $72 \mathrm{~h}$ ). The crude acetone extract and partitions were stored at $4^{\circ} \mathrm{C}$ for further biological assays, fractionation, and isolation.

Fractionation and Isolation of Diterpenoids from the root of $A$. Amatymbica.

Ethyl acetate partition $(25 \mathrm{~g})$ was pre-absorbed on Si-gel to produce a slurry, then freeze-dried at $-55^{\circ} \mathrm{C}$ and Si-gel $(625 \mathrm{~g})$ was loaded on a $640 \mathrm{~mm}$ by $60 \mathrm{~mm}$ chromatographic column. Subsequently, eluted with different polarity of acetone-ethyl acetate solvent system. The fractions were collected from the column, purified by PTLC to give five compounds (1) (60mg), (2) (62.1mg), (3) (52mg), (4) (108mg), and (5) (62mg) from $\mathrm{F}_{8-19}(100 \mathrm{mg}), \mathrm{F}_{75-87}(87 \mathrm{mg}), \mathrm{F}_{52-64}(80 \mathrm{mg}), \mathrm{F}_{20-28}$ (310mg), and $\mathrm{F}_{35-45}(74 \mathrm{mg})$, respectively.

All the compounds were identified by the comparison with the data in the literature and the extensive analysis of IR, 1D and 2D NMR involving COSY, HSQC, and HMBC spectra. Figure 1 shows the molecular structure of the compounds.

\section{Analytical data}

Diterpenoids 1-5 were isolated in this investigation from an ethyl acetate fraction of the A. amatymbica root, and derivative of diterpenoids 1, 3-4 had previously been isolated. ${ }^{13-16}$

i. Ent-13-hydroxy-16-kauren-19-oic acid (1): a colourless crystalline solid. Melting point: $215-216^{\circ} \mathrm{C} . \mathrm{V}_{\max }\left((\mathrm{KBr}) / \mathrm{cm}^{-1} 3331(\mathrm{v}\right.$, $\mathrm{O}-\mathrm{H}), 1600,1475$ (v, C=C), 3100 (v, =C-H), 1250, 1050 (v, C-O), $1710(\mathrm{v}, \mathrm{C}=\mathrm{O}) . \mathrm{M} / \mathrm{z}$ (HRMS EI) 318.2195; $\mathrm{C}_{20} \mathrm{H}_{30} \mathrm{O}_{3}$ requires $\left[\mathrm{M}^{+}\right]$319.5882. - $\left(300 \mathrm{MHz},\left(\mathrm{CD}_{3}\right)_{2} \mathrm{CO}\right) 2.24(\mathrm{~d} \mathrm{~J} 2.7,2 \mathrm{H}), 1.20(\mathrm{~m}$, $2 \mathrm{H}), 1.75(\mathrm{~m}, 2 \mathrm{H}), 1.75(\mathrm{~m}, 1 \mathrm{H}), 1.92(\mathrm{~m}, 2 \mathrm{H}), 1.20-1.75(\mathrm{~m}$, $2 \mathrm{H}), 2.61(\mathrm{~m}, 2 \mathrm{H}), 1.87(\mathrm{~m}, 2 \mathrm{H}), 1.64-1.66(\mathrm{~m} 2 \mathrm{H}), 1.31(\mathrm{~m}$,
2H), 2.95 (s, 2H), 2.89 (s, 2H), 4.78 ( s, 2H) $4.72(\mathrm{~s}, 2 \mathrm{H}), 1.20$ $(\mathrm{s}, 3 \mathrm{H}), 1.13(\mathrm{~s}, 3 \mathrm{H})$ (Supporting File 1 for full experimental data). $\delta_{\mathrm{c}}\left(300 \mathrm{MHz},\left(\mathrm{CD}_{3}\right)_{2} \mathrm{CO}\right) 41.3(\mathrm{C}-1), 19.0(\mathrm{C}-2), 39.8(\mathrm{C}-3)$, 43.3(C-4), 55.5(C-5), 126.5(C-6), 133(C-7), 39.4(C-8), 61.3(C9), 38.6(C-10), 34.0(C-11), 21.9(C-12), 49.9(C-13), 37.9(C-14), 58.6(C-15), 82.5(C-16), 28.5(C-17), 25.3(C-18), 178.3(C-19), 15.3(C-20) (Supporting File 2 for full experimental data).

ii. 16-hydroxy-kaur-6-en-19-oic acid (2): a white crystalline. Melting point: $230-232^{\circ} \mathrm{C} . \mathrm{V}_{\max }(\mathrm{KBr}) / \mathrm{cm}^{-1} 3450(\mathrm{v}, \mathrm{O}-\mathrm{H}), 1642$, $1470(\mathrm{v}, \mathrm{C}=\mathrm{C}), 3080(\mathrm{v},=\mathrm{C}-\mathrm{H}), 1240(\mathrm{v}, \mathrm{C}-\mathrm{O}), 1715(\mathrm{v}, \mathrm{C}=\mathrm{O})$. $\mathrm{M} / \mathrm{z}$ (HRMS EI) 318.2195; $\mathrm{C}_{20} \mathrm{H}_{30} \mathrm{O}_{3}$ requires $\left[\mathrm{M}^{+}\right]$318.2216. (300MHz, $\left.\left(\mathrm{CD}_{3}\right)_{2} \mathrm{CO}\right) 5.94(\mathrm{t}, \mathrm{J} 7.2,1 \mathrm{H}), 5.55(\mathrm{dd}, \mathrm{J} 2.7 \mathrm{1H}), 2.19$ (d, J 2.4), 2.16, (s, 2H), $1.87(\mathrm{~m}, 2 \mathrm{H}), 1.80$ (d, J 1.5, 2H), 1.79 (m, $2 \mathrm{H}), 1.75(\mathrm{~m}, 2 \mathrm{H}), 1.44(\mathrm{~m}, 1 \mathrm{H}), 1.39(\mathrm{~m}, 2 \mathrm{H}), 1.38-1.53(\mathrm{~m}, 2 \mathrm{H})$, $1.25(\mathrm{~s}, 3 \mathrm{H}), 1.20(\mathrm{~s}, 3 \mathrm{H}), 1.15(\mathrm{~s}, 1 \mathrm{H}), 0.88,(\mathrm{~s}, 3 \mathrm{H})$ (Supporting File 3 for full experimental data). $\delta_{\mathrm{c}}\left(300 \mathrm{MHz},\left(\mathrm{CD}_{3}\right)_{2} \mathrm{CO}\right)$ 40.4(C-1), 19.1(C-2), 37.8(C-3), 49.4(C-4), 49.3(C-5), 32.2(C6), 34.3(C-7), 43.9(C-8), 42.5(C-9), 43.3(C-10), 21.9(C-11), 28.9(C-12), 76.4(C-13), 36.1(C-14), 43.8(C-15), 155.8(C-16), 102.5(C-17), 28.6(C-18), 178.6(C-19), 17.3(C-20) (Supporting File 4 for full experimental data).

iii. 14-acetoxy ent- kaur-16-en-19-oic acid (3): is a white crystalline solid. Melting point: $219-220^{\circ} \mathrm{C} . \mathrm{V}_{\max }(\mathrm{KBr}) / \mathrm{cm}^{-1} 2971(\mathrm{v}$, $\mathrm{O}-\mathrm{H}), 1664,1470$ (v, C=C), $3016(\mathrm{v},=\mathrm{C}-\mathrm{H}), 1188(\mathrm{v}, \mathrm{C}-\mathrm{O}), 1739$ (v, C=O). M/z (HRMS EI) 376.2250; $\mathrm{C}_{22} \mathrm{H}_{32} \mathrm{O}_{5}$ requires $\left[\mathrm{M}^{+}\right]$

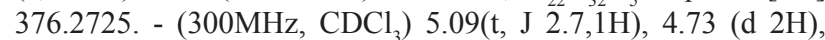
$2.68(\mathrm{~d}, 1 \mathrm{H}), 2.56(\mathrm{~m}, 2 \mathrm{H}), 2.18(\mathrm{~m}, 2 \mathrm{H}), 1.98(\mathrm{~m}, 2 \mathrm{H}), 1.98(\mathrm{~s}$, $3 \mathrm{H}), 1.90(\mathrm{~m}, 2 \mathrm{H}), 1.88(\mathrm{~m}, 2 \mathrm{H}), 1.63(\mathrm{~m}, 2 \mathrm{H}), 1.33(\mathrm{t}, 1 \mathrm{H}), 1.28$ $(\mathrm{s}, 3 \mathrm{H}), 1.24(\mathrm{~m}, 2 \mathrm{H}), 1.15(\mathrm{t}, 1 \mathrm{H}), 1.01(\mathrm{~m}, 2 \mathrm{H}), 0.94(\mathrm{~s}, 3 \mathrm{H})(\mathrm{Su}-$ pporting File 5 for full experimental data). $\delta_{\mathrm{c}}\left(300 \mathrm{MHz}, \mathrm{CDCl}_{3}\right)$ 39.2 (C-1), 19.0 (C-2), 41.1 (C-3), 38.6 (C-4), 56.9 (C-5), 21.7 (C-6), 37.7 (C-7), 43.8 (C-8), 60.9 (C-9), 43.1 (C-10), 40.2 (C11), 47.8 (C-12), 42.2 (C-13), 69.4 (C-14), 39.5 (C-15), 155.1 (C 16), 103.2 (C-17), 29.0 (C-18), 183.7 (C-19), 15.4 (C-20), 170.1 (C-21), 21.6 (C-22) (Supporting File 6 for full experimental data).

iv. 14-oxokaur-16-en-19-oic acid (4): is a brown waxy liquid. $\mathrm{M} / \mathrm{z}$ (HRMS EI) 332.1988; $\mathrm{C}_{20} \mathrm{H}_{28} \mathrm{O}_{4}$ requires $\left[\mathrm{M}^{+}\right] 332.1445 . \mathrm{V}_{\text {max }}$ $(\mathrm{KBr}) / \mathrm{cm}^{-1} 2971(\mathrm{v}, \mathrm{O}-\mathrm{H}), 1651(\mathrm{v}, \mathrm{C}=\mathrm{C}), 3008(\mathrm{v},=\mathrm{C}-\mathrm{H}), 1296$ (v, C-O), $1721(\mathrm{v}, \mathrm{C}=\mathrm{O})$. - (300 MHz, $\left.\mathrm{CDCl}_{3}\right) 5.0(\mathrm{~s}, 2 \mathrm{H}), 4.90$ $(\mathrm{s}, 2 \mathrm{H}), 2.77(\mathrm{~s}, 1 \mathrm{H}), 2.20-2.40(\mathrm{~m}, 2 \mathrm{H}), 2.15-2.35(\mathrm{~m}, 2 \mathrm{H}), 1.75$ (d, J $3.6,2 \mathrm{H}), 1.66(\mathrm{~m}, 2 \mathrm{H}), 1.61(\mathrm{~m}, 2 \mathrm{H}), 1.57-1.75(\mathrm{~m}, 2 \mathrm{H})$, $1.50(\mathrm{~m}, 2 \mathrm{H}), 1.40-1.70(\mathrm{~m}, 2 \mathrm{H}), 1.40-1.60(\mathrm{~m}, 2 \mathrm{H}), 1.39(\mathrm{~s}, 3 \mathrm{H})$, $1.12(\mathrm{~s}, 3 \mathrm{H})$ (Supporting File 7 for full experimental data). $\delta$ (300MHz, $\left.\mathrm{CDCl}_{3}\right)$ 43.5(C-1), 19.6(C-2), 36.7(C-3), 48.3(C-4), 55.6(C-5), 35.9(C-6), 41.8(C-7), 56.9(C-8), 84.9(C-9), 22.0(C10), 36.5(C-11), 32.8(C-12), 42.1(C-13), 212.9(C-14), 33.6 (C-15), 152.0 (C-16), 106.9(C-17), 22.0(C-18), 180.4(C-19), 18.0(C-20) (Supporting File 8 for full experimental data).

v. 14-acetoxo-12-oxokaur-16-en-19-oic acid (5): is a brown waxy solid. M/z (HRMS EI) 390.2037; $\mathrm{C}_{22} \mathrm{H}_{30} \mathrm{O}_{6}$ requires $\left[\mathrm{M}^{+}\right]$ 390.2024. $\mathrm{V}_{\max }(\mathrm{KBr}) / \mathrm{cm}^{-1} 3120,(\mathrm{v}, \mathrm{O}-\mathrm{H}), 1664$, (v, C=C), 3010 $(\mathrm{v},=\mathrm{C}-\mathrm{H}), 1379,1296(\mathrm{v}, \mathrm{C}-\mathrm{O}), 1712,1730,1755(\mathrm{v}, \mathrm{C}=\mathrm{O}) 3120$, 1470 (v, O-H). - (300MHz, $\left.\mathrm{CDCl}_{3}\right) 5.08(\mathrm{~s}, 2 \mathrm{H}), 4.99(\mathrm{~s}, 2 \mathrm{H}), 4.92$ (d, J 3.0, 1H), 2.89 (s 1H), 2.37(m, 2H), 2.19-2.52(s,1H), 2.19 (s, 3H), 2.13-2.52 (m, 2H), 1.83 (m, J 2.7, 2H), 1.83 (d, J 2.7, $2 \mathrm{H}), 1.71(\mathrm{~m}, 2 \mathrm{H}), 1.55(\mathrm{~s}, 3 \mathrm{H}), 1.51(\mathrm{~m}, 2 \mathrm{H}), 1.48-2.19(\mathrm{~m}, 2 \mathrm{H})$, $1.22(\mathrm{~s}, 3 \mathrm{H})$ (Supporting File 9 for full experimental data). $\delta_{\mathrm{c}}$ 
(300MHz, $\left.\mathrm{CDCl}_{3}\right)$ 41.9(C-1), 33.5(C-2), 32.7(C-3), 30.9(C-4), 48.6(C-5), 33.7(C-6), 33.0(C-7), 57.0(C-8), 85.5(C-9), 52.5(C10), 36.0 (C-11), 213.2(C-12), 42.2(C-13), 73.0(C-14), 43.6(C-
15), 152.0(C-16), 107.0(C-17), 21.9(C-18), 178.2(C-19), 15.5(C20), 170.2(C-21), 21.2(C-22) (Supporting File 10 for full experimental data).

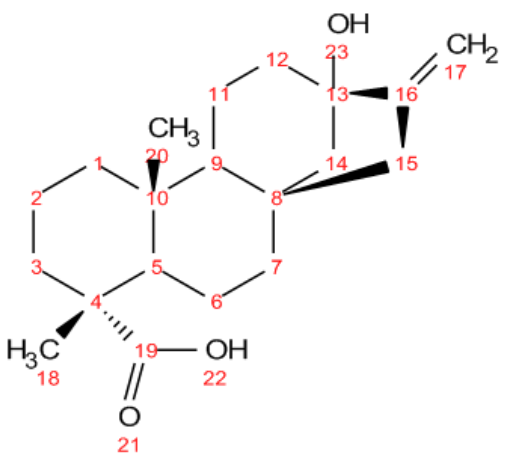

13-hydroxy-kaur-16-en-19-oicacid (1)

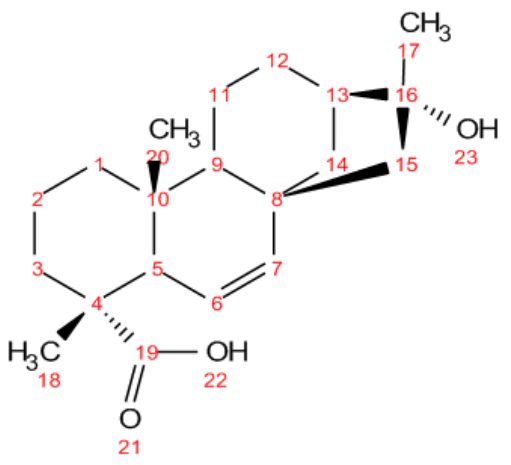

16-hydroxy-kaur-6-en-19-oic-acid (2)

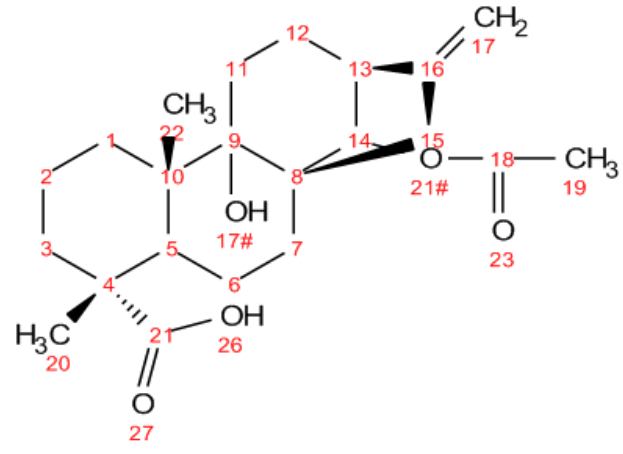

14-acetoxy ent- kaur-16-en-19-oic acid (3)

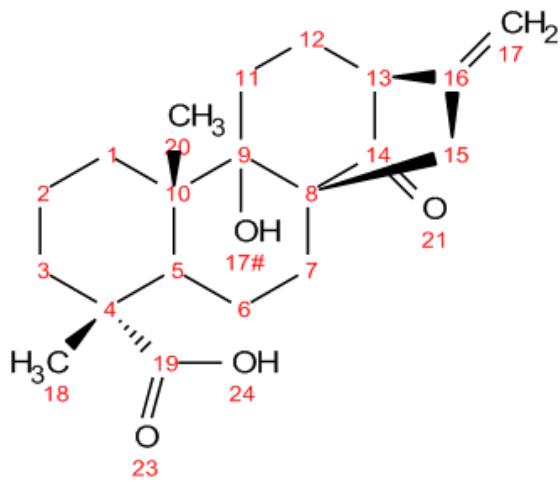

14-oxokaur-16-en-19-oic acid (4)

Figure I Chemical structures of diterpenoids isolated from A. Amatymbica.

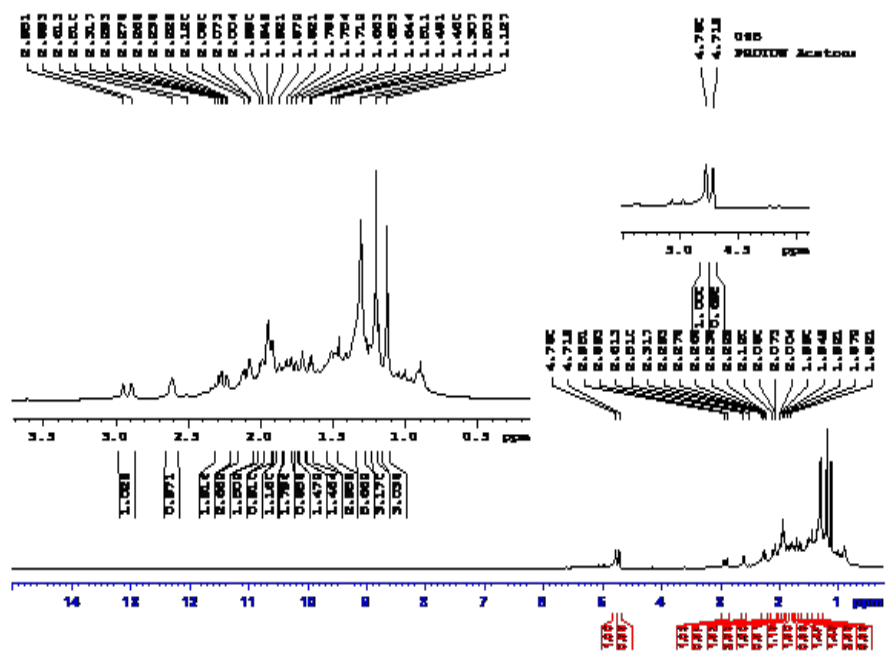

Supporting File I 'H NMR Spectrum for Compound I.

\section{Thin layer chromatography}

Compounds 1-5 were developed on a TLC silica gel $60 \mathrm{~F}_{254} \mathrm{Al}-$ sheets using ethyl acetate in acetone as the mobile phase. ${ }^{17}$ After development, the chromatograms were subjected to direct TLC bioautographic assay.

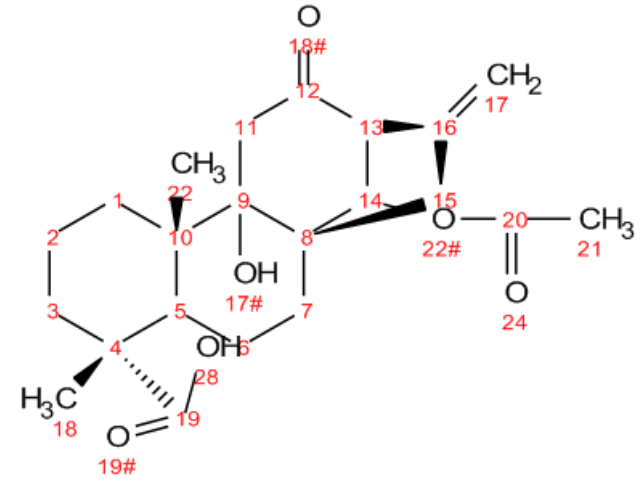

14-acetoxo-12-oxokaur-16-en-19-oic acid (5)

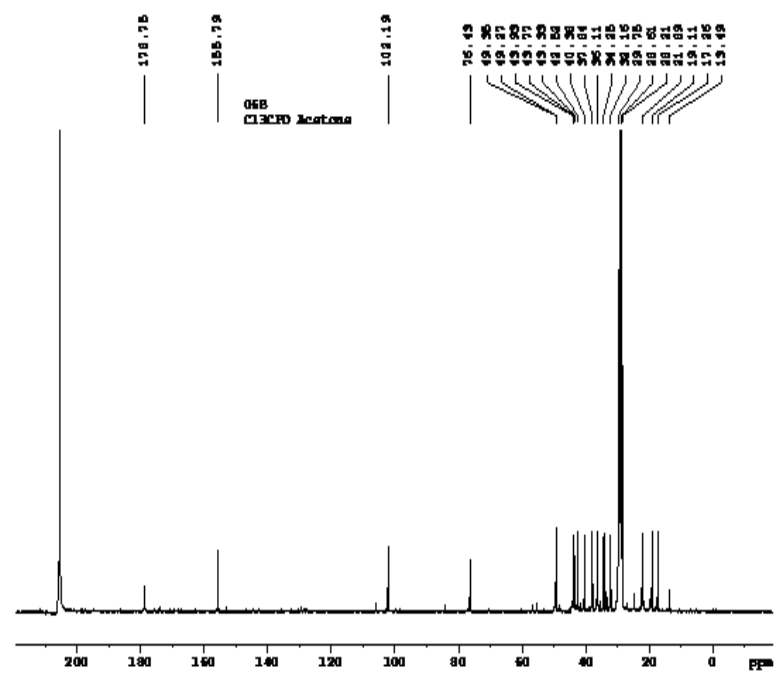

Supporting File $2{ }^{13} \mathrm{C}$ NMR Spectrum for Compound I.

\section{Direct TLC bioautographic assay}

The air dried chromatograms were sprayed in an esco class II biological safety cabinet (Esco Technologies) with the inoculum suspension of Staphylococcus aureus (ATCC 29213), Pseudomonas aeruginosa (ATCC 27853), Enterococcus faecalis (ATCC 29212), and 
Escherichia coli (ATCC 25922) cells. The sprayed chromatograms were incubated at $37^{\circ} \mathrm{C}$ for $24 \mathrm{~h}$ with $100 \%$ relative humidity in the dark. Solution of 2-(4-Iodophenyl)-3-(4-nitrophenyl)-5-phenyl-2Htetrazolium chloride $(2 \mathrm{mg} / \mathrm{ml})$ were sprayed on the bioautograms ${ }^{18}$ and are re-incubated at $37^{\circ} \mathrm{C}$ for $3 \mathrm{~h} .{ }^{19}$ Bacteria growth inhibition is confirmed by white bands on a purple background, indicating the reduction of 2-(4-Iodophenyl)-3-(4-nitrophenyl)-5-phenyl-2Htetrazolium chloride to formazan. The zone of inhibition of compounds with antibacterial activity was measured. ${ }^{19-21}$
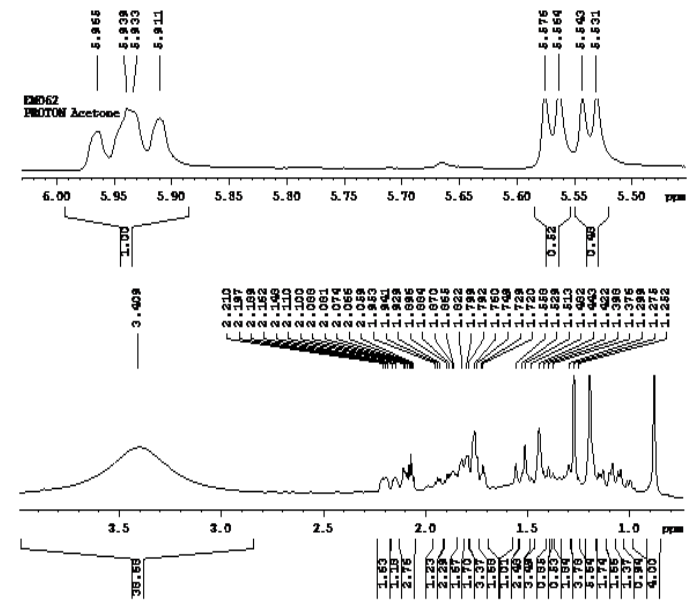

Supporting File 3 'H NMR spectrum $(300 \mathrm{MHz})$ for Compound 2.

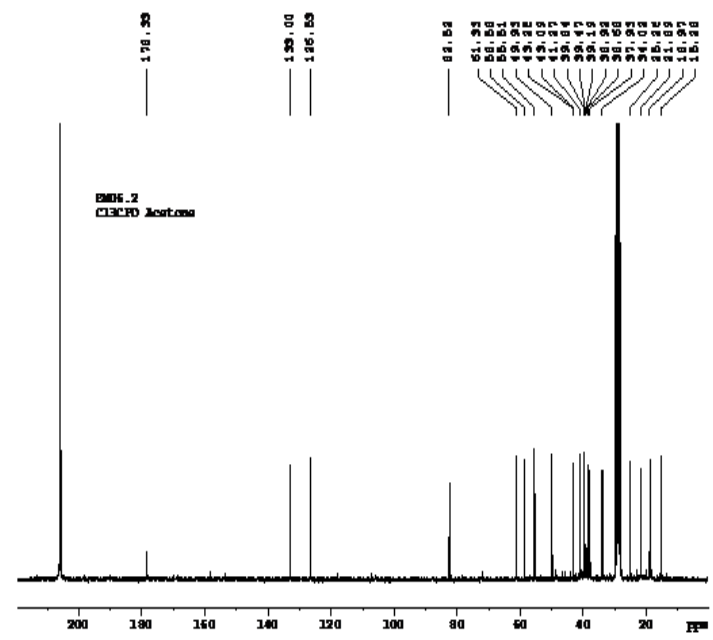

Supporting File 4 'C NMR spectrum (300 MHz) for Compound 2.

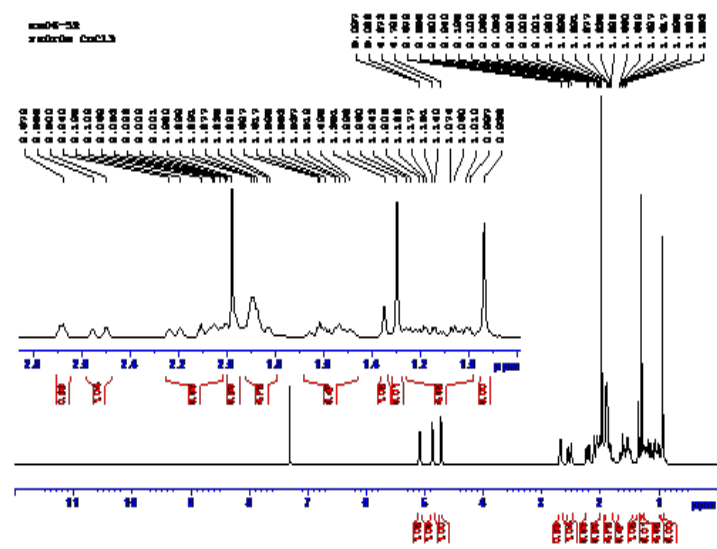

Supporting File 5 'H NMR spectrum for Compound 3.

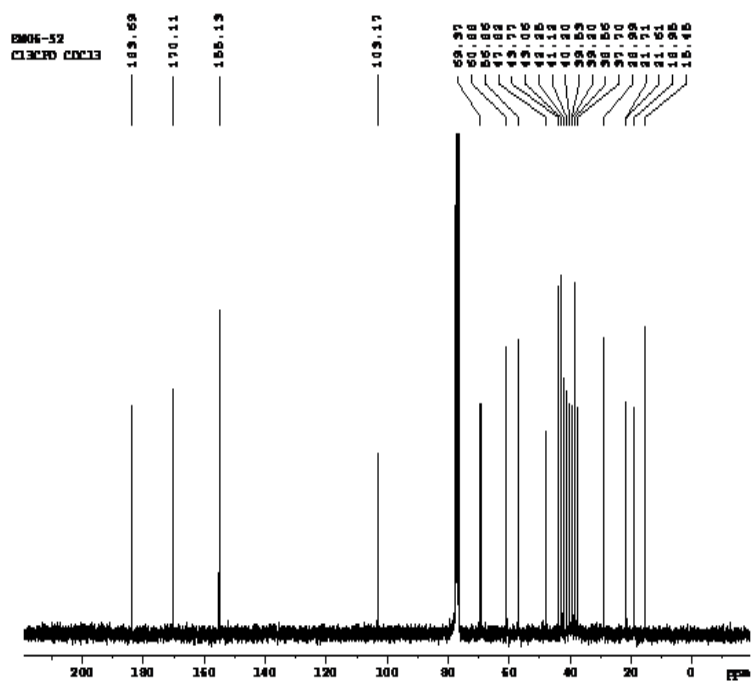

Supporting File 6 'C NMR spectrum $(300 \mathrm{MHz})$ for Compound 3.

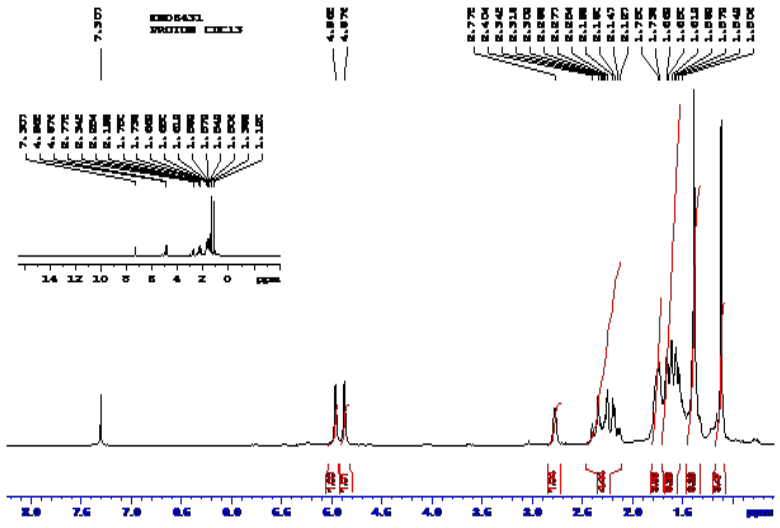

Supporting File 7 'H NMR spectrum $(300 \mathrm{MHz})$ for Compound 4.

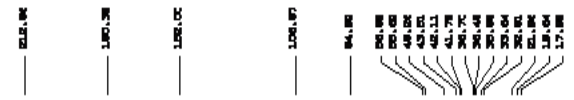

עom

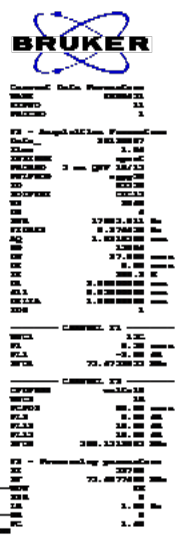

Supporting File $8{ }^{13} \mathrm{C}$ NMR spectrum for Compound 4.

\section{Minimum inhibitory concentrations (mic)}

Minimum inhibitory concentrations of the compounds 1-5 were determined using 96-well microtitre plate against $S$. aureus, $P$. aeruginosa, E. faecalis and E. coli. 2-(4-Iodophenyl)-3-(4nitrophenyl)-5-phenyl-2H-tetrazolium chloride was used as a growth indicator. ${ }^{22}$ In brief, $100 \mu \mathrm{L}$ distilled water was dispensed into each well using a multichannel micropipette. After that, $100 \mu \mathrm{L}$ of compound $(10 \mathrm{mg} / \mathrm{ml})$ was added to the first well of the column and 
serially diluted to obtain a working solution of concentrations 5.000 $-0.078 \mathrm{mg} / \mathrm{ml}$. Gentamycin and DMSO were used as positive and negative controls.

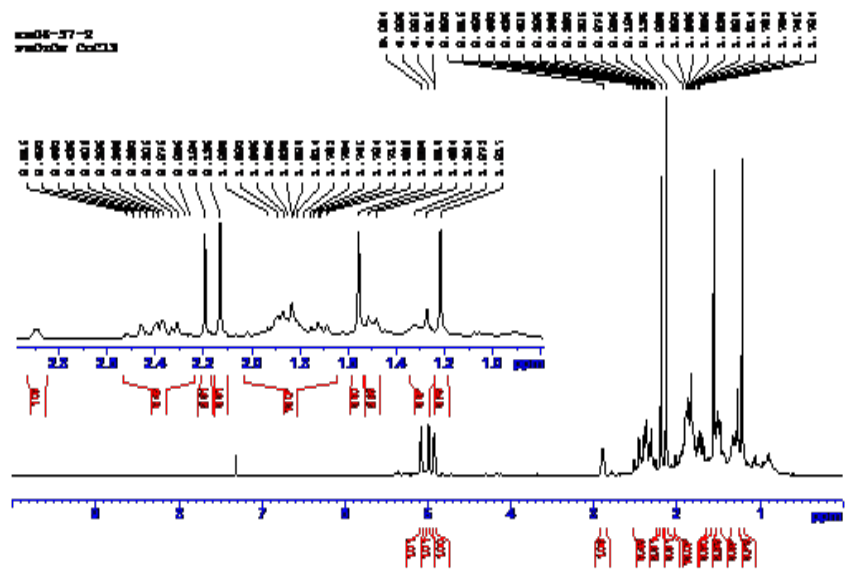

Supporting File 9 'H NMR spectrum (300 MHz) for Compound 5.

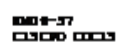

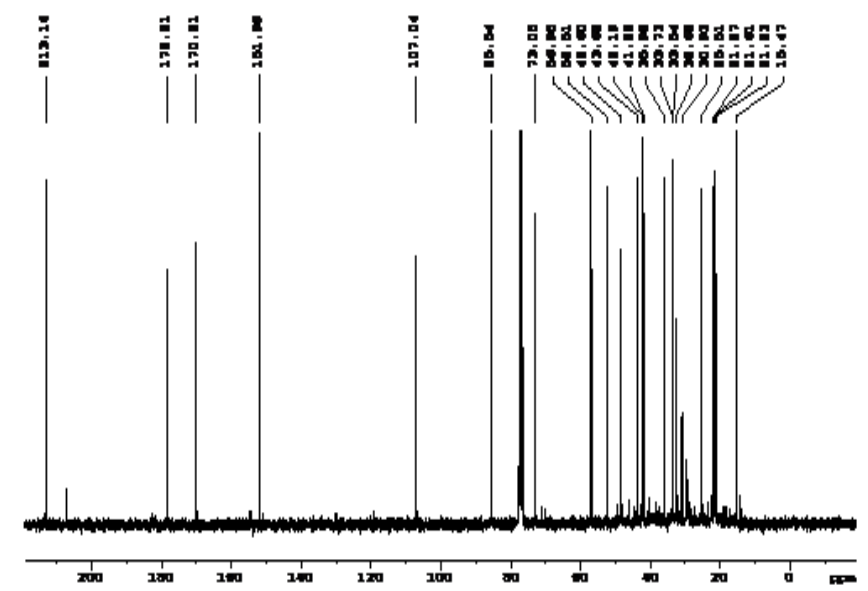

Supporting File $10{ }^{13} \mathrm{C}$ NMR spectrum $(300 \mathrm{MHz})$ for Compound 5 .

\section{Lipoxygenase inhibition assay}

Inhibitory activity of the compounds against 15-soybean lipoxygenase (15-LOX) was evaluated as described by Malterud \& Rydland $^{23}$ in a borate buffer $(0.2 \mathrm{M}, \mathrm{pH} 9.00)$. Absorbance was read at $234 \mathrm{~nm}$ using UV-vis spectrophotometer for $5 \mathrm{~min}$ at an interval of 30 sec after addition of 15-LOX, using linoleic acid $(134 \mu \mathrm{M})$ as substrate. The enzyme solution was kept on the ice, and controls (1.6\% DMSO) were measured at intervals throughout the experiment to ensure that the activity was constant. All the reactions were performed in triplicates. The percentage of inhibition was calculated as:

$\%$ Inhibition $=\frac{A_{c}-A_{t_{c}}}{A_{c}} \times 100 \%$

Where

$\mathrm{A}_{\mathrm{c}}=$ absorbance of control

$\mathrm{A}_{\mathrm{tc}}=$ absorbance of the test compound

\section{Cytotoxicity assay}

Dermal mesenchymal stem cells line (DMSC) and monkey Vero cells (ATCC ${ }^{\circledR}$ CCL-81 ${ }^{\mathrm{TM}}$ ), harvested and centrifuged at $200 \mathrm{RPM}$ for $5 \mathrm{~min}$. The cells line were maintained in Minimal Essential Medium (MEM) to $1 \times 10^{6} \mathrm{cell} / \mathrm{s} / \mathrm{ml} /$ well, supplemented with gentamicin $(0.1 \%)$ (Virbac) and foetal calf serum (5\%). ${ }^{24}$ A cell suspension $(200 \mu \mathrm{l})$ was pipetted into well 2 to 11 of the sterile 96-well microtitre plate; the MEM was aspirated from the cells, and replaced with $200 \mu \mathrm{l}$ of test compounds. At $37^{\circ} \mathrm{C}$ the cells were cultured at a humidity of $5 \% \mathrm{CO}_{2}$ incubator for $24 \mathrm{~h}$. After the incubation period, MTT $(20 \mu 1,5 \mathrm{mg} / \mathrm{mL})^{2}$ was added to each well and incubated for another $4 \mathrm{~h}$ until purple precipitates were visible under a microscope. The concentration of MTT was measured immediately at 570 and $630 \mathrm{~nm}$ (reference) using a Plate reader. The blank was made up of the medium and MTT with no cells in wells in column 1 . The concentration of the compounds resulting in a $50 \%$ reduction of absorbance compared to untreated cells is reported as the LC50.

\section{Results and discussion}

\section{Characterization of ent-13-hydroxy-16-kauren-19-oic acid (I)}

${ }^{13} \mathrm{C}-\mathrm{NMR}$ reveals an exocyclic double bond resonances at $\delta 155.8$ (C-16) and at 102.5 (C-17), a carbonyl resonance at 178.6 (C-19), an oxymethine carbon resonance at $\delta 73.4$ (C-13) which is typical of a kaurenoic acid. ${ }^{15-16}{ }^{1} \mathrm{H}$ NMR showed the presence of two methyl groups with proton resonance at $\delta 1.20(\mathrm{~s}, 3 \mathrm{H}, \mathrm{H}-20)$, and $\delta 1.13(\mathrm{~s}$, $3 \mathrm{H}, \mathrm{H}-18) \mathrm{ppm}$. The DEPT-135 pulse sequence produces ten methene $\left(\mathrm{CH}_{2}\right)$ carbons with a total of 20 carbon atoms. The COSY spectrum indicates that proton $\delta 4.72(\mathrm{~s}, \mathrm{H}-17)$ coupled with the protons $\delta 1.64$ $1.66(\mathrm{~m}, \mathrm{H}-12)$. The two singlet protons $\delta 2.89$ and $2.95 \mathrm{ppm}(2 \mathrm{H}, \mathrm{s}$, $\mathrm{H}-14)$ also exhibited coupling with $\delta 1.64-1.66(2 \mathrm{H}, \mathrm{m}, \mathrm{H}-12)$ and also with $\delta 2.24$ (d, J 2.7, H-15). The COSY spectrum also displays a correlation between $\delta 2.61 \mathrm{ppm}(\mathrm{m}, 2 \mathrm{H}, \mathrm{H}-9)$ with $\delta 1.20$ (s, 3H, H-20) and protons $\delta 2.24(\mathrm{~d}, \mathrm{~J} 2.7, \mathrm{H}-1)$. The position of the $-\mathrm{OH}$ group was as a result of the HMBC correlation of $\delta 1.31(\mathrm{~m}, 2 \mathrm{H}, \mathrm{H}-11)$ and $\delta 1.92(\mathrm{~m}, 2 \mathrm{H}, \mathrm{H}-12)$ with the quaternary carbon $\mathrm{C}-13$. Compound 1 , therefore, was classified as a 13-hydroxy-kaur-16-en-19-oic acid.

\section{Characterization of 16-hydroxy-kaur-6-en-19-oic acid} (2)

${ }^{13} \mathrm{C}-\mathrm{NMR}$ showed olefinic carbons resonances at $\delta 126.4(\mathrm{C}-6)$ and at 133.0ppm (C-7), a carbonyl carbon resonance at 178.3ppm(C-19), an oxymethine carbon resonance at $\delta 82.5 \mathrm{ppm}(\mathrm{C}-16)$ which are the characteristics of a kaurenoic acid. ${ }^{15}$ DEPT 135 pulse sequence produces seven methene $\left(\mathrm{CH}_{2}\right)$ carbons with a total of 20 carbon atoms. ${ }^{1} \mathrm{H}$ NMR showed the presence of three methyl groups with proton resonances at $\delta 0.88(\mathrm{~s}, 3 \mathrm{H}, \mathrm{H}-20), \delta 1.25 \mathrm{ppm}(\mathrm{s}, 3 \mathrm{H}, \mathrm{H}-18)$, and $81.93 \mathrm{ppm}(\mathrm{s}, 3 \mathrm{H}, \mathrm{H}-17)$. The proton on $85.55 \mathrm{ppm}$, (dd, J 2.7, $\mathrm{H}-6$ ), and $\delta 5.94 \mathrm{ppm}$, (t, J 7.2, H-7), are deshielded by the $\pi$ bond between the two carbons. The position of the $\mathrm{OH}$ group at $\mathrm{C}-16$ was as a result of coupling displayed by the HMQC spectrum with the methyl protons on $\mathrm{H}-17$. The double bond placement on $\mathrm{C}-6$ is justified by the HMQC spectrum that revealed a ${ }^{3} \mathrm{~J}$ proton correlation between the $\mathrm{H}-7$ proton $\delta 5.94(\mathrm{t}, \mathrm{J} 7.2,1 \mathrm{H})$ with $\mathrm{C}-14$ protons $\delta 2.16 \mathrm{ppm},(\mathrm{s}, 2 \mathrm{H})$, hence the double bond is between $\mathrm{C}-6(\delta 126.5 \mathrm{ppm})$ and $\mathrm{C}-7(\delta 133.0 \mathrm{ppm})$. HMBC spectrum also showed coupling of proton $\mathrm{H}-18(\delta 0.88 \mathrm{ppm})$ ${ }^{3} \mathrm{~J}$ correlation with the tertiary carbon C-19 ( $\left.\delta 178.3 \mathrm{ppm}\right)$. Similar the derivatives; $15 \alpha$-hydroxy-ent-kaur-16-en-19oic acid and ent-12 $\beta$ hydroxykaur-16-en-19-oic acid have been reported. ${ }^{25-26}$ Compound 2 was therefore named as 16- hydroxy-kaur-6- en-19-oic-acid. 
Characterization of I4- acetoxy ent- kaur- I 6-en- I 9-oic acid (3)

${ }^{1} \mathrm{H}$ NMR displayed the presence of three methyl groups with protons resonating at $\delta 1.23 \mathrm{ppm}(\mathrm{s}, \mathrm{H}-18)$ and $\delta 0.94(\mathrm{~s}, \mathrm{H}-20)$ and the relatively deshielded $\delta 1.98 \mathrm{ppm}(\mathrm{s}, \mathrm{H}-22)$ because it's in the same chemical environment as the carbonyl group at $\mathrm{C}-21 .{ }^{13} \mathrm{C}-\mathrm{NMR}$ shows exocyclic alkene carbon resonances at $\delta 155.1 \mathrm{ppm}(\mathrm{C}-16)$ and 103.2ppm (C-17), a carbonyl carbon resonance at $170.1 \mathrm{ppm}$ (C-21), an oxymethine carbon resonance at $\delta 69.4 \mathrm{ppm}(\mathrm{C}-14)$. The DEPT-135 pulse sequence produces nine methene $\left(\mathrm{CH}_{2}\right)$ carbons with a total of 22 carbon atoms. There is a direct correlation between $\mathrm{C}-17$ and the $\mathrm{H}-17$ and also $\mathrm{C}-14$ and $\mathrm{H}-14$ on the HSQC spectrum. The COSY spectrum indicates that proton $\delta 4.73, \mathrm{~s}(\mathrm{C}-17)$ is coupled with the protons $\delta 1.98$ $(\mathrm{s}, 3 \mathrm{H})(\mathrm{C}-22)$. The position of the $\mathrm{O}-\mathrm{COCH}_{3}$ group at $\mathrm{C}-14$ was as a result of the $\mathrm{H}-14{ }^{3} \mathrm{~J}$ coupling with the $\mathrm{C}-17$ ( 8103.2$)$. Also, the $\mathrm{H}-13$ ( $\delta 2.68)$ displaying a ${ }^{1} \mathrm{~J}$ coupling with the $\mathrm{C}-17(\delta 103.2)$, as confirmed by the HMBC spectrum. In comparison Somova et al. ${ }^{26}$ who isolated $11 \alpha$-acetoxy ent- kaur-16-en-19-oic acid, an isomer of compound (3) which only differ by the position of the acetoxy group. Compound 3 was therefore classified as a 14-acetoxy ent-kaur-16-en-19-oic acid.

Characterization of I4-oxokaur-I6-en-I9-oic acid (4)

${ }^{13} \mathrm{C}-\mathrm{NMR}$ reveals olefin carbons resonating at $\delta 106.9$ (C-17) Table I ${ }^{2} \mathrm{~J} / 3 \mathrm{~J}$ coupling from HMBC and COSY for compound (I)-(5) and $\delta 152.0$ (C-16), a carbonyl carbon resonance at $\delta 180.4$ (C-19), a resonance typical of an oxymethine carbon at $\delta 84.9$ (C-9). ${ }^{1} \mathrm{H}$ NMR displayed the presence of two methyl groups with proton resonance at $\delta 1.39(\mathrm{~s}, \mathrm{H}-20)$ and $\delta 1.20(\mathrm{~s}, \mathrm{H}-18)$ and exocyclic proton resonances 84.90-5.0 (s, H-17). The DEPT-135 pulse sequence produces nine methene $\left(\mathrm{CH}_{2}\right)$ carbons with a total of 20 carbon atoms. The HSQC reveals that the carbon at $106.9(\mathrm{C}-17)$ is directly attached to the two protons at $\mathrm{H}-17(5.0$ and $4.90 \mathrm{ppm})$, which agrees with its DEPT 135 methylene peak classification. Also, the 41.8 (C-7) is in direct correlation with the methylene protons at $\mathrm{H}-7$. The position of the keto group on $\mathrm{C}-14$ was based on the COSY spectrum which established a correlation between $\mathrm{H}-17$ protons coupling with $\mathrm{H}-12, \mathrm{H}-13$, and $\mathrm{H}-15$ protons. The - $\mathrm{OH}$ group position on $\mathrm{C}-9$ was determined based on its correlation with $\mathrm{H}-20$ protons. A summary of all the ${ }^{1} \mathrm{~J},{ }^{2} \mathrm{~J}$, and ${ }^{2} \mathrm{~J}$ coupling is presented in Table 1 . HMBC spectrum also displayed a correlation of $\mathrm{H}-18(\delta 1.12)$ proton, coupling with $\mathrm{C}-2,(\delta 36.5)$, and C-3 ( 836.7$)$ placing the C-20 methyl group on quaternary C- 10 . Compound 4 was therefore classified as 14-oxokaur-16-en-19-oic acid, a functional group isomer of $15 \beta$-acetoxy-(-)-kaur-16-en-19-oic acid synthesised by acetylation of 15ß-Hydroxy-(-)-kaur-16-en-19oic acid..$^{27,28}$ Compound 4 is the first isolation of an oxo derivative of 15ß-Hydroxy-(-)-kaur-16-en-19-oic acid from A. amatymbica.

\begin{tabular}{|c|c|c|c|c|c|}
\hline & Compound (I) & Compound (2) & Compound (3) & Compound (4) & Compound (5) \\
\hline Carbon & ${ }^{2} \mathbf{J} /{ }^{3} \mathbf{J}$ & ${ }^{2} \mathbf{J} /{ }^{3} \mathbf{J}$ & ${ }^{2} \mathbf{J} / 3$ & ${ }^{2} \mathbf{J} / \mathbf{J}$ & ${ }^{2} \mathbf{J} / 3 \mathbf{J}$ \\
\hline 1 & & $55.5,82.5$ & $56.9,47.8,37.7$ & $55.6,36.7,36.5$ & $\begin{array}{l}\text { I52.0, 42.2, } \\
33.5,32.7\end{array}$ \\
\hline 2 & $49.4,43.3,37.8$ & $61.3,43.3$ & 183.7 & & $32.7,21.9,41.9$ \\
\hline \multicolumn{6}{|l|}{3} \\
\hline 4 & - & - & - & & \\
\hline 5 & $17.3,28.6,34.3,32.2$ & 178.3,61.3, 38.6, 43.3, & $60.9,15.4 ., 39.2,19.0$ & & 213.2 \\
\hline 6 & $76.4,42.5$ & $61.3,49.9,43.3$ & I55.1 & 55.6, 48.3, & \\
\hline 7 & $76.4,43.9,42.5$ & $61.3,49.9,37.9$ & 21.7 & & $21.9,41.9$ \\
\hline 8 & - & - & - & & \\
\hline 9 & 34.3 & & $69.4,56.9,47.843 .8,38.6, \mathrm{I}$ & & \\
\hline 10 & - & - & - & & \\
\hline 11 & & & 15.4 & 36.7 & 170.2 \\
\hline 12 & & $28.5 q$ & 43.8 & 152.5 & \\
\hline 13 & & $\begin{array}{l}\text { I33.0, I26.5, 82.5, 61.3, } \\
4 \mid .3\end{array}$ & $60.9,103.2$ & & \\
\hline 14 & $76.4,43.9,28.9,17.3$ & $\begin{array}{l}133.0,126.5,82.5,58.6 \text {, } \\
41.3\end{array}$ & 103.2 & & 15.5 \\
\hline 15 & & $133.0,82.5,61.3,34.0$ & 15.4 & 56.9 & \\
\hline 16 & - & - & - & - & - \\
\hline 17 & & $82.5,58.6,49.9$ & 42.2 & $33.6,41.8,42.1$ & 42.2 \\
\hline 18 & $\begin{array}{l}49.3,43.9,37.8,178.6, \\
36.1\end{array}$ & $\begin{array}{l}178.3,55.5,39.8,43.3 \\
34.0\end{array}$ & $15.4,69.4,56.9,42.3,37.7$ & $\begin{array}{l}33.6,33.7,48.3,55.6 \\
180.4\end{array}$ & $\begin{array}{l}\text { I 78.2, 73.0, 52.5, } \\
48.6\end{array}$ \\
\hline 19 & - & - & - & & \\
\hline 20 & $32.2,43.9,49.3,76.4$ & $55.5,4 \mathrm{I} .3,38.6$ & $56.9,39.2,60.9$ & $55.6,43.5,33.6,33.7,84.9$ & $32.7,48.6,85.5$ \\
\hline 21 & & & - & & \\
\hline 22 & & & & & 213.2 \\
\hline
\end{tabular}

Citation: Muleya E, Joseph OB, Mtunzi FM, et al. Diterpenoids of alepidea amatymbica eckl. \& zeyh: studies of their cytotoxic, antimicrobial and lipoxygenase inhibitory activities. MOJ Biorg Org Chem. 20I7; I(3): I03-III.DOI: 10.15406/mojboc.2017.01.00019 


\section{Characterization of |4-acetoxo-12-oxokaur-16-en- -19-oic acid (5)}

${ }^{13} \mathrm{C}-\mathrm{NMR}$ showed an exocyclic double bond resonating at $\delta 152.0 \mathrm{ppm}(\mathrm{C}-16)$ and $107.0 \mathrm{ppm}(\mathrm{C}-17)$, three carbonyl resonances at $\delta 178.2(\mathrm{C}-19), \delta 170.2(\mathrm{C}-12)$ and $\delta 213.2(\mathrm{C}-12)$, typical oxymethine carbons resonance at $\delta 85.5$ (C-9) and $\delta 73.5$ (C-19). ${ }^{1} \mathrm{H}$ NMR - (400 $\mathrm{MHz}, \mathrm{CDCl}_{3}$ ): showed the presence of three methyl groups with proton resonances at $\delta 2.19(\mathrm{~s}, \mathrm{H}-22), 1.22(\mathrm{~s}, \mathrm{H}-21)$ and $1.55(\mathrm{~s}$, $\mathrm{H}-18$ ). These signals agree with the report of Somova et al. ${ }^{26}$ \& Langat et al. ${ }^{15}$ on kaurenoid isolation and characterisation. The DEPT-135 pulse sequence produces eight methene $\left(\mathrm{CH}_{2}\right)$ carbons with a total of 22 carbon atoms. The HSQC reveals that the carbon at 106.9(C$17)$ is directly attached to the two protons at $\mathrm{H}-17(5.0$ and $4.90 \mathrm{ppm})$, which agrees with its DEPT 135 methylene peak classification. Also, the 41.8 (C-7) is in direct correlation with the methylene protons at $\mathrm{H}-7$. The position of the keto group on $\mathrm{C}-12$ was based on the COSY spectrum which established a correlation between $\mathrm{H}-17$ protons coupling with $\mathrm{H}-13$, and $\mathrm{H}-14$ protons. The $-\mathrm{OH}$ group position on C-9 was determined based on the H-9 correlation with H-22 protons. A summary of all the ${ }^{1} \mathrm{~J},{ }^{2} \mathrm{~J}$, and ${ }^{2} \mathrm{~J}$ coupling is presented in Table 1. HMBC spectrum also displayed a correlation of $\mathrm{H}-21(\delta 2.19, \mathrm{~s}, 3 \mathrm{H})$ proton, Coupling with $\mathrm{C}-20(\delta 36.5)$ placing the $\mathrm{C}-21$ methyl group on quaternary $\mathrm{C}-20$. The diterpenoid contains both the acetate group on $\mathrm{C}-14$, carboxylic acid group at $\mathrm{C}-4$ and a keto group on $\mathrm{C}-12$. The name proposed for compound (5) is 14-acetoxo-12-oxokaur-16-en19-oic acid.

\section{TLC antibacterial bioautography assay of pure compounds I-5}

Compounds 1-5 were screened on the selected organism to determine the susceptibility and MIC. ${ }^{29,30}$ The sensitivity test by the direct TLC bioautographic assay showed clear zones of inhibition at a concentration of $10 \mathrm{mg} / \mathrm{ml}$, with differing percentages of $19.26 \%$ S. aureus, . aeruginosa, E. faecalis, and E. coli. P. aeruginosa and E. faecalis were the most sensitive organism to all the compounds; this is in agreement with the antimicrobial report of kaurenoid acid and its epimer; xylopic. ${ }^{31}$ 14-acetoxo-12-oxokaur-16-en-19-oic acid (5) is the most potent against $S$. aureus, E, faecalis, and E.coli with a MIC $125 \mu \mathrm{g} / \mathrm{ml}$ while $14-$ acetoxy ent- kaur-16-en-19-oic acid (3) has a MIC of $125 \mu \mathrm{g} / \mathrm{ml}$ against $P$. aeruginosa (Figure 2). The structureactivity relationship of compound 3 and 5 explains the potency; the $\mathrm{C}-14$ acetate enhances the antibiotic activity of the diterpenoids and the further substitution by the oxo group at position C-12. Liu et al. ${ }^{32}$ reported that acetylation increases the activity and ability of the molecule to cross the selectively permeable membrane. Also, acetylation helps a given drug reach the target site more quickly, making the effect of the medication's more intense and increasing the effectiveness of a given dose. ${ }^{33}$

The lower MIC of compounds 3 and 5 establishes their possible application as a complementary antibiotic, and the presence of these bioactive diterpenoids confirms the antibacterial activity of $A$. amatymbica reported in the literature ${ }^{34}$ and entho-medicinally. ${ }^{35}$

\section{Inhibition of lipoxygenase activity of compound I-5}

Literature has shown that cell metabolism and apoptosis are regulated by signalling pathways of lipoxygenase.$^{36}$ Excessive release of lipoxygenase metabolites has been implicated in proliferative cancer cell, stroke, arthritis, asthma, cancer, inflammation, and many other diseases conditions. ${ }^{37-42}$ Hence, lipoxygenase is an essential enzyme for designing selective and safe inhibitors suitable for medical application. The highest lipoxygenase inhibition at a concentration of $100 \mu \mathrm{g} / \mathrm{ml}$ was displayed by 14 -acetoxo-12-oxokaur16-en-19-oic acid (5) followed by 14-acetoxy ent-kaur-16-en-19-oic acid (3) with 16-hydroxy-kaur-6-en-19-oic acid (2) demonstrating the least inhibitory activity when compared to the positive control of indomethacin (Figure 3).

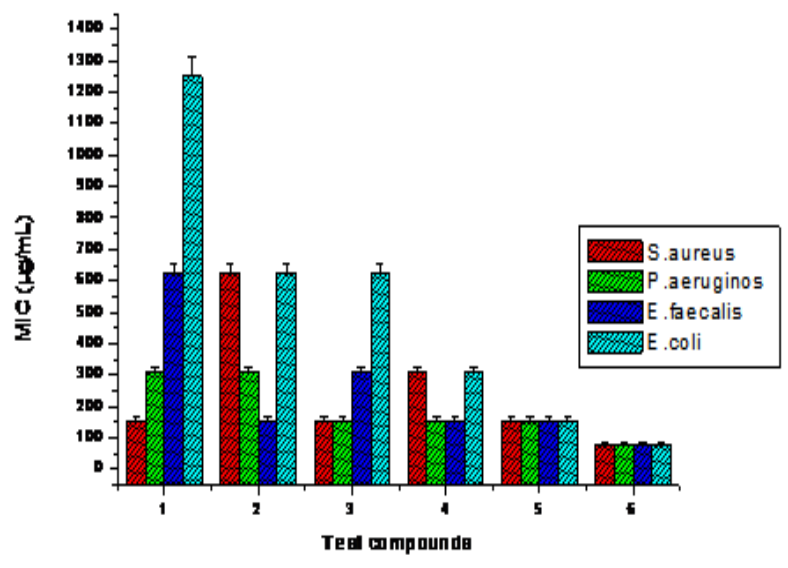

Figure 2 Antibiotic activities expressed as MIC $(\mu \mathrm{g} / \mathrm{ml})$ for compounds I-5.

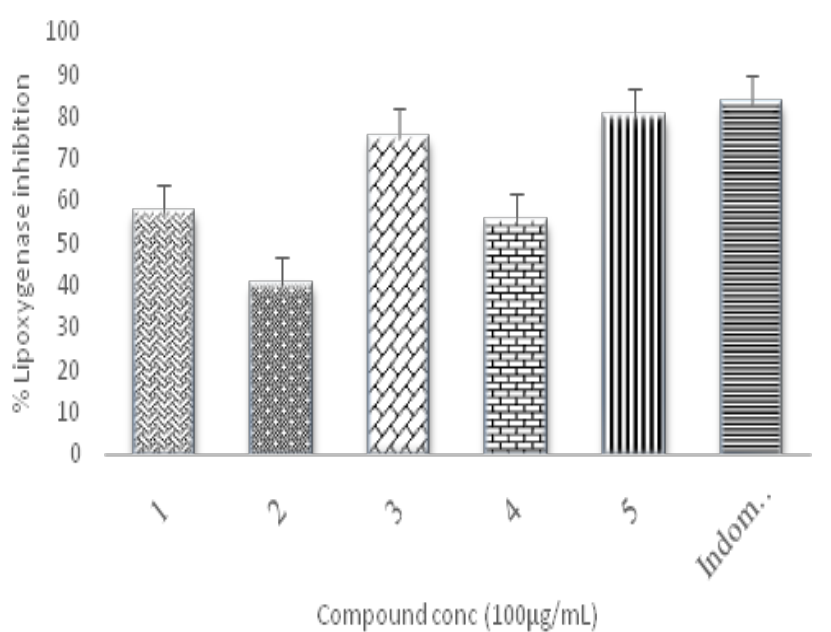

Figure 3 \% Soyabean derived I5-LOX- Inhibition by compounds I-5.

Our results showed that only Compound 5 exhibited a significant inhibition $\left(\mathrm{EC}_{50}\right.$ of $\left.19.10 \pm 3.15 \mu \mathrm{g} / \mathrm{ml}\right)$, Compound $3\left(\mathrm{EC}_{50}\right.$ of $25.98 \pm 1.12 \mu \mathrm{g} / \mathrm{ml})$, and compound $4\left(\mathrm{EC}_{50}\right.$ of $\left.42.76 \pm 3.22 \mu \mathrm{g} / \mathrm{ml}\right)$ displayed moderate LOX activity. Compound 2 and 1 had an effective concentration of $81.18 \pm 7.50 \mu \mathrm{g} / \mathrm{ml}$ and $60.37 \pm 5.64 \mu \mathrm{g} / \mathrm{ml}$ respectively, consequently, exhibited moderate activity.

Previous reports on the petroleum ether and dichloromethane extracts of $A$. amatymbica root have been reported to demonstrate COX-1 and COX-2 inhibition. ${ }^{43}$ This observed activity is attributed to the presence of 14- acetoxy ent- kaur-16-en-19-oic acid (3) and 14-acetoxo-12-oxokaur-16-en-19-oic acid (5) due to their significant $\mathrm{EC}_{50}$. These findings should, therefore, be cautiously applied to the anti-inflammatory activity in humans because the mechanism of human-derived 15 LOX differs slightly from LOX, soybean lipoxygenase.

\section{Cytotoxic effects of the compounds I-5}

Aqueous extracts of $A$. amatymbica root screened against cancerous 
cells did not show toxicity at all test concentration as reported in literature. ${ }^{44}$ The root has found application as leads for the development therapeutic drug in clinical medicine, but the cytotoxicity of isolated compounds need to be established. ${ }^{45}$ The cytotoxicity results showed potent cytotoxic effects on bovine dermis cells with compounds 1-5 (Figure 4) with an $\mathrm{IC}_{50}$ less or equal to the stringent value noted for cancerous bovine dermis which is in agreement with NCI criteria. ${ }^{46}$ The American National Cancer Institute (NCI) guidelines limit the activity of a pure compound at $50 \%$ inhibition $\left(\mathrm{IC}_{50}\right)$ of a proliferation of less than $30 \mu \mathrm{g} / \mathrm{mL}$ after the exposure time of 72 hours. ${ }^{47}$

These data are also of interest as it suggests that the compounds are more toxic to cancer cells than on normal cells. The investigation provides evidence for the cytotoxicity of $A$. amatymbica towards bovine dermis which may be due to existing diterpenoids as reported in the previous preliminary study. ${ }^{44,48}$

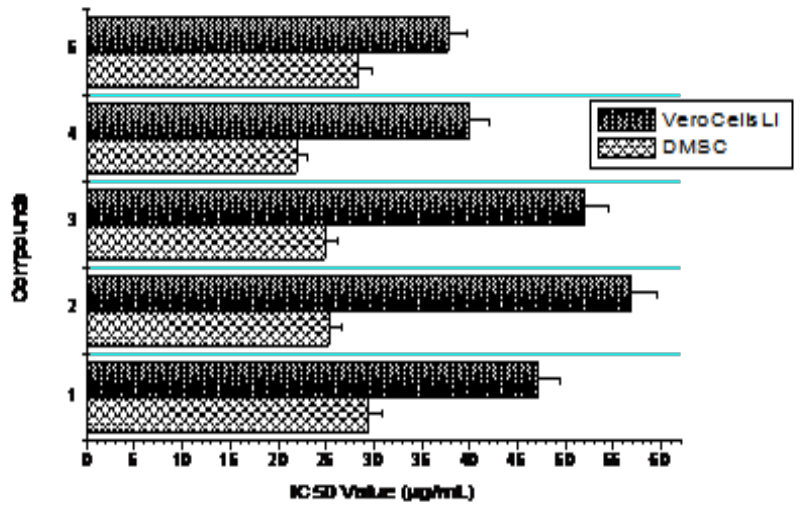

Figure 4 Cytotoxic effects of diterpenoids I-5 against DMSC and Vero cell lines.

\section{Conclusion}

In this study, we isolated five diterpenic acids; 13-hydroxy16-kauren-19-oic acid (1), 16-hydroxy-kaur-6-en-19-oic acid (2), 14-acetoxy ent-kaur-16-en-19-oic acid (3), 14-oxokaur-16-en-19oic acid (4), and 14-acetoxo-12-oxokaur-16-en-19-oic acid (5). The bioautographic assay showed that all the diterpenoids were potential antimicrobial diterpenoid with $P$. aeruginosa and $E$. faecalis been very sensitive to all test diterpenoids. 14-acetoxo-12-oxokaur-16-en19 -oic acid is the most potent against $S$. aureus, E. faecalis, and E.coli at MIC $125 \mu \mathrm{g} / \mathrm{ml}$, with a relatively high lipoxygenase inhibition activity when compared to standard indomethacin. These isolated diterpenoids did not show toxicity to normal but toxic to tumour cell lines. Thus, we conclude that $A$. amatymbica contain components such as diterpenic acids, which are responsible for contributing to antiinflammatory effects and other biological activities. The acetylated diterpenic acids have potent biological activities and no toxicity of the diterpenoid from A. amatymbica root. This isolated diterpenoids can be synthesised and acetylated to confirm the in vivo activities.

\section{Acknowledgements}

We appreciate University of Pretoria Phytomedicine Programme, the Chemistry Department, University of Botswana, and the Vaal University of Technology, for providing the facilities for the study. Conflict of interest

The author declares no conflict of interest.

\section{References}

1. Maksimovi Z, Dobri S, Kovaevi N, et al. Diuretic activity of Maydis stigma extract in rats. Pharmazie. 2004;59(12):967-971.

2. Burtt BL. Umbelliferae of southern Africa: an introduction and annotated checklist. Edinburgh J Bot. 1991;48(2):133-282.

3. OA Wintola, AJ Afolayan. Alepidea amatymbica Eckl. \& amp; Zeyh. A review of its traditional uses, photochemistry, pharmacology, and toxicology. Evidence-based Complement Altern Med. 2014;2014:11.

4. S Nonjinge, BB Tarr. Natal National Botanical Garden. 2013.

5. Louvel S, Moodley N, Seibert I, et al. Identification of compounds from the plant species Alepidea amatymbica active against HIV. South African J Bot. 2013;86:9-14.

6. Spellberg B, Guidos R, Gilbert D, et al. The Epidemic of Antibiotic-Resistant Infections: A Call to Action for the Medical Community from the Infectious Diseases Society of America. Clin Infect Dis. 2008;46(2):155-164.

7. Srivastava HB, Srivastava V, Srivastava RK, et al. Structural Analyses of the Crystalline Rocks between Dirang and Tawang, West Kameng District, Arunachal Himalaya. Journal of the Geological Society of India. 2011;78:45-56.

8. Van Wyk BE, Van Oudtshoom B, Gericke N. Medicinal plants of South Africa. 2nd ed. South Africa: Briza Publications; 1997.

9. Van Wyk BE, Gericke N. People's Plants: A Guide to Useful Plants of Southern Africa. South Africa: Briza Publications; 2000.

10. Olivier DK, Van Wyk BE. The major diterpenoids of the genus Arctopus (Apiaceae) with notes on their chemotaxonomic and medicinal significance. South African J Bot. 2013;85:94-98.

11. Lutterodt GD. Inhibition of gastrointestinal release of acetylchoune byquercetin as a possible mode of action of Psidium guajava leaf extracts in the treatment of acute diarrhoeal disease. J Ethnopharmacol. $1989 ; 25(3): 235-247$.

12. Conkerton EJ, Wan PJ, Richard OA. Hexane and heptane as extraction solvents for cottonseed:A laboratory-scale study. J Am Oil Chem Soc. 1995;72(8):963-965.

13. Court WE, Hardman R. Medicinal and aromatic plants: Industrial profiles. USA: Taylor \& Francis, CRC Press; 2006.

14. Aparicio R, Bahsas A, Usubillaga A. Allylic oxidation of en t-Kaurenic acid, ent-Kaurenic acid Methyl Ester and ent-Kaurenol. Avances en Química. 2007;2(3):3-8.

15. Langat MK, Crouch NR, Pohjala L, et al. Ent-kauren-19-oic acid derivatives from the stem bark of Croton pseudopulchellus Pax. Phytochem Lett. 2012;5(3):414-418.

16. Batista R, Garcí PA, Castro MA, et al. New oxidized ent-kaurane and ent-norkaurane derivatives from kaurenoic acid. J Braz Chem Soc. 2007; 18(3):622-627.

17. Masoko P, Gololo SS, Mokgotho MP, et al. Evaluation of the antioxidant, antibacterial, and antiproliferative activities of the acetone extract of the roots of Senna italica (Fabaceae). Afr J Tradit Complement Altern Med. 2010;7(2):138-148.

18. Begue JW, Kline MR. The use of tetrazolium salts in bioauthographic procedures. J Chromatogr. 1972;64(1):182-184.

19. Dilika F, Afolayan AJ, Meyer JJM. Comparative antibacterial activity of two Helichrysum species used in male circumcision in South Africa. $S$ Afr J Bot. 1997;63(3):158-159. 
20. Runyoro DK, Matee MI, Ngassapa OD, et al. Screening of Tanzanian medicinal plants for anti-Candida activity. BMC Complement Altern Med. 2006;6(1):11.

21. Suleimana MM, McGaw LJ, Naidoo V, et al. Detection of Antimicrobia Compounds by Bioautography of Different Extracts of Leaves of Selected South African Tree Species. Afr J Tradit Complement Altern Med. 2010;7(1):64-78.

22. Eloff J. A quick Microplate Method to Determine the Minimum Inhibitory Sensitive and Concentration of Plant Extracts for Bacteria. Planta Medica. 1998;64(2):711-713.

23. Malterud KE, Rydland KM. Inhibitors of 15-Lipoxigenase from Orange Peel. J Agric Food Chem. 2000;48(11):5576-5580.

24. Mosmann T. Rapid colorimetric assay for cellular growth and survival: application to proliferation and cytotoxicity assays. J Immunol Methods. 1983;65(1-2):55-63.

25. Ortega A, Morales FJ, Salmon M. Kaurenic acid derivatives from Stevia eupatoria. Phytochemistry. 1985;24:1850-1852.

26. Moodley K, Govender Y, Somova LI, et al. Cardiovascular and diuretic activity of kaurene derivatives of Xylopia aethiopica and Alepidea amatymbica. J Ethnopharmacol. 2001;77(2-3):165-174.

27. Silva E, Takahashi J, Boaventura MA, et al. The biotransformation of ent-kaur-16-en-19-oic acid by Rhizopus stolonifer. 1999;52:397-400.

28. Silva J, Abebe W, Sousa SM, et al. Analgesic and anti-inflammatory effects of essential oils of Eucalyptus. J Ethnopharmacol. 2003;89(23):277-283.

29. Dewanjee S, Gangopadhyay M, Bhattacharya N, et al. Bioautography and its scope in the field of natural product chemistry. Journal of Pharmaceutical Analysis. 2015;5(2):75-84.

30. Department of Basic Education. Government Gazette Staatskoerant Government Gazette. 2014;583(37230):1-4.

31. Davino SC, Giesbrecht AM, Roque NF. Antimicrobial activity of kaurenoic acid derivatives substituted on carbon-15. Brazilian Braz J Med Biol Res. 1989;22(9):1127-1129.

32. Liu J, Head E, Kuratsune H, et al. Comparison of the effects of L-carnitine and acetyl-L-carnitine on carnitine levels, ambulatory activity, and oxidative stress biomarkers in the brain of old rats. Ann N Y Acad Sci. 2004;1033:117-131.

33. Koide K, Osman S, Garner AL, et al. The use of 3,5,4'-Tri-O-acetylresveratrol as a Potential Prodrug for Resveratrol protects mice from $\gamma$-Irradiation-induced death. ACS Med Chem Lett. 2011;2(4):270-274.

34. Maroyi A. Ethnobotanical study of two threatened medicinal plants in Zimbabwe. International Journal of Biodiversity Science \& Management. 2008;4(3):148-153.
35. Gelfand M, Mavi S, Drummond RB, et al. The Traditional Medical Practictioner in Zimbabwe. Zimbabwe: Mambo Press; 1985.

36. Phillis JW, Horrocks LA, Farooqui AA. Cyclooxygenases, lipoxygenases, and epoxygenases in CNS: their role and involvement in neurological disorders. Brain Res Rev. 2006;52(2):201-243.

37. Fürstenberger G, Krieg P, Müller-Decker K, et al. What are cyclooxygenases and lipoxygenases doing in the driver's seat of carcinogenesis? Int $J$ Cancer. 2006;119(10):2247-2254

38. Jatana M, Giri S, Ansari MA, et al. Inhibition of NF-kappaB activation by 5 -lipoxygenase inhibitors protects brain against injury in a rat model of focal cerebral ischemia. J Neuroinflammation. 2006;3:12.

39. Araico A, Terencio MC, Alcaraz MJ, et al. Evaluation of the anti-inflammatory and analgesic activity of $\mathrm{Me}-\mathrm{UCH} 9$, a dual cyclooxygenase-2/5lipoxygenase inhibitor. Life Sci. 2007;80(23):2108-2117.

40. Berger W, De Chandt MTM, Cairns CB. Zileuton: clinical implications of 5-Lipoxygenase inhibition in severe airway disease. Int J Clin Pract. 2007;61(4):663-676.

41. Steele VE, Holmes CA, Hawk ET, et al. Lipoxygenase Inhibitors as Potential Cancer Chemopreventives. Cancer Epidemiol Biomarkers Prev. $1999 ; 8(5): 467-483$.

42. Federico A, Morgillo F, Tuccillo C, et al. Chronic inflammation and oxidative stress in human carcinogenesis. Int J Cancer. 2007;121(11):23812386.

43. Mulaudzi RB. Seed Germination and Medicinal Properties of Alepidea Species. South Africa: University of KwaZulu-Natal Pietermaritzburg Campus; 2009. p. 1-105.

44. Treurnicht FT. An evaluation of the toxic and d potential an tiviral effects of some plants used by South Africans for medicinal purposes. South Africa: University of Stellenbosch; 1997.

45. Van Wyk BE, de Castro A, Tilney PM, et al. A new species of Alepidea (Apiaceae, subfam. Saniculoideae). South African Journal of Botany. 2008;74(4):740-745.

46. Mahavorasirikul W, Viyanant V, Chaijaroenkul W, et al. Cytotoxic activity of Thai medicinal plants against human cholangiocarcinoma, laryngeal and hepatocarcinoma cells in vitro. BMC Complement Altern Med. 2010;10:55.

47. Abdel-Hameed ESS, Bazaid SA, Shohayeb MM, et al. Phytochemical Studies and Evaluation of Antioxidant, Anticancer and Antimicrobial Properties of Conocarpus erectus L. Growing in Taif, Saudi Arabia. European Journal of Medicinal Plants. 2012;2(2):93-112.

48. Muleya E. Evaluation of biological activities of nine anti-inflammatory medicinal plants and characterization of antimicrobial compounds from Pomaria sandersonii and Alepidea amatymbica MSc (Analytical Chemistry). South Africa: Vaal University of Technology; (unpublished). 